\title{
Familial hypocalciuric hypercalcaemia and acute pancreatitis
}

\author{
M DAVIES, P S KLIMIUK, P H ADAMS, G A LUMB, D M LARGE, D C ANDERSON
}

\begin{abstract}
Four families with familial hypocalciuric hypercalcaemia were studied. The probands presented with abdominal pain, which in three was due to acute pancreatitis; in two the condition was life threatening. Serum concentrations of calcium, magnesium, phosphate, and immunoassayable parathyroid hormone, urinary calcium excretion, and the rate of renal tubular reabsorption of phosphate were measured; the findings were compared with results in 10 patients with primary hyperparathyroidism matched for serum calcium concentration to establish differences between the diseases.

Familial hypocalciuric hypercalcaemia should be suspected in patients with hypercalcaemia in whom daily urinary calcium excretion is below $5 \mathrm{mmol}(200 \mathrm{mg}$ ) provided renal insufficiency, vitamin $D$ deficiency, and ingestion of drugs that reduce calcium excretion have been excluded. Most cases appear to run a benign course, but some may suffer considerable morbidity. Surgical treatment should be reserved for patients with severe complications, when all parathyroid tissue should be removed.
\end{abstract}

\section{Introduction}

Primary hyperparathyroidism is occasionally familial and then usually presents with bone disease, renal stones, peptic ulcer, and occasionally pancreatitis. ${ }^{1}$ The condition is inherited as an

\footnotetext{
Department of Metabolism, University of Manchester, Royal Infirmary, Manchester M13 9WL

M DAVIES, MRCP, senior lecturer in medicine

P S KLIMIUK, MRCP, lecturer in medicine

P H ADAMS, FRCP, professor of medicine

G A LUMB, PHD, senior lecturer in medical chemistry

Department of Medicine, University of Manchester, Hope Hospital, Salford M6 8HD

D M LARGE, MRCP, MRC research fellow

D C ANDERSON, FRCP, senior lecturer in medicine and endocrinology
}

autosomal dominant and may exist alone or in combination with other endocrine abnormalities; both forms may arise through hyperplasia of all the parathyroid glands or a single adenoma. ${ }^{1}$ Another form of familial hypercalcaemia-namely, familial hypocalciuric hypercalcaemia-although inherited as an autosomal dominant, differs from typical primary hyperparathyroidism in that the renal excretion of calcium is reduced. ${ }^{2}$ Patients with this disorder are commonly thought to have primary hyperparathyroidism ${ }^{4}$; and while many of those operated on have been shown to have parathyroid hyperplasia, subtotal parathyroidectomy usually fails to correct the hypercalcaemia. ${ }^{2-5}$ The clinical course of the reported cases appears to be mild, and renal and other complications of hypercalcaemia are exceptional. ${ }^{6}$ Many patients have been discovered fortuitously.

We observed four patients with familial hypocalciuric hypercalcaemia who presented with abdominal pain. Three had acute pancreatitis, two of whom were gravely ill.

\section{Methods and case reports}

Three index patients were studied in a metabolic ward and one in a general ward. Members of their families were studied either in the ward or as outpatients.

Concentrations of calcium, magnesium, inorganic phosphate, and creatinine in serum and urine were measured as previously described. ${ }^{7}$ The renal tubular maximum reabsorption rate for phosphate ${ }^{8}$ (TmP/GFR; range $0.8-1.35 \mathrm{mmol} / 1$ glomerular filtrate $(2 \cdot 48-4.2$ $\mathrm{mg} / 100 \mathrm{ml}$ glomerular filtrate)) and the fasting urinary calcium excretion ${ }^{9}$ were measured in fasting samples of urine and serum obtained between 0800 and 1100 . Serum immunoassayable parathyroid hormone (range $0-0.8 \mu \mathrm{g} / \mathrm{l}$ ) was measured by radioimmunoassay. ${ }^{10}$ All the observations were made with the patients taking a free diet, and no drugs were given at the time of the studies. Statistical differences between groups were assessed by Student's $t$ test and the Wilcoxon rank sum test where applicable.

INDEX CASE 1

A 12-year-old Kenyan Asian boy was admitted to the metabolic unit in 1976 for investigation of attacks of upper abdominal pain and vomiting. Primary hyperparathyroidism was diagnosed (serum 
calcium concentration $3.02 \mathrm{mmol} / 1(12.1 \mathrm{mg} / 100 \mathrm{ml})$, magnesium $0.8 \mathrm{mmol} / 1(1.9 \mathrm{mg} / 100 \mathrm{ml})$, phosphate $1.13 \mathrm{mmol} / 1(3.5 \mathrm{mg} / 100 \mathrm{ml})$, serum immunoassayable parathyroid hormone $1.0 \mu \mathrm{g} / \mathrm{l})$; a subtotal parathyroidectomy was performed for parathyroid hyperplasia. Three months later the hypercalcaemia recurred (calcium $2.85 \mathrm{mmol} / 1$ $(11.4 \mathrm{mg} / 100 \mathrm{ml})$, immunoassayable parathyroid hormone $0.6 \mu \mathrm{g} / \mathrm{l})$, and an attack of acute pancreatitis (serum amylase activity 7600 IU/l) was treated conservatively. At a second neck exploration the remaining parathyroid tissue was removed. He developed hypocalcaemia, which was controlled with oral calcium supplements, and subsequently remained in good health. His asymptomatic relatives with hypercalcaemia (father and five siblings) were observed for four years and remained well.

\section{INDEX CASE 2}

A 29-year-old Caucasian man was admitted in 1977 for investigation of hypercalcaemia and recurrent pancreatitis. Cholecystectomy and ampullary sphincterotomy had been performed in December 1976 after three episodes of acute pancreatitis. In February 1977 he was readmitted in shock with haemoglobin concentration $6 \mathrm{~g} / \mathrm{dl}$. He was later transferred to the metabolic unit and shown to have a large lesser-sac haematoma, which was drained surgically. Investigations showed serum calcium concentration $2.88 \mathrm{mmol} / 1(11.5 \mathrm{mg} / 100 \mathrm{ml})$, magnesium $1.03 \mathrm{mmol} / 1(2.5 \mathrm{mg} / 100 \mathrm{ml})$, phosphate $0.84 \mathrm{mmol} / 1$ $(2.6 \mathrm{mg} / 100 \mathrm{ml}), \mathrm{TmP} / \mathrm{GFR} 1.05 \mathrm{mmol} / 1$ glomerular filtrate $(3.3 \mathrm{mg} /$ $100 \mathrm{ml}$ glomerular filtrate), 24-hour urinary calcium $2.5 \mathrm{mmol}(100$ $\mathrm{mg}$ ), and immunoassayable parathyroid hormone $<0.1 \mu \mathrm{g} / \mathrm{l}$. The hypercalcaemia persisted during a standard hydrocortisone suppression test. ${ }^{11} \mathrm{He}$ remained gravely ill with pancreatitis, and because he might have primary hyperparathyroidism the neck and superior mediastinum were explored surgically. Two parathyroid glands of normal size and histology were removed; no other parathyroid tissue was identified. Postoperatively he remained hypercalcaemic and oral phosphate treatment was started. Outpatient follow-up showed a serum calcium concentration varying between 2.6 and $2.8 \mathrm{mmol} / 1(10.4$ and $11.2 \mathrm{mg} / 100 \mathrm{ml})$, but he had no further episodes of pancreatitis.

Investigation of his family showed hypercalcaemia in his mother, two sisters, and a daughter (fig 1); all were well.

\section{INDEX CASE 3}

A 26-year-old Caucasian man was referred for investigation of recurrent episodes of upper abdominal pain. After a severe episode he was admitted elsewhere and found to be hypercalcaemic. Investigation showed calcium $2.8 \mathrm{mmol} / 1(11.2 \mathrm{mg} / 100 \mathrm{ml})$, magnesium 0.92 $\mathrm{mmol} / 1(2.2 \mathrm{mg} / 100 \mathrm{ml})$, phosphate $0.83 \mathrm{mmol} / 1(2.6 \mathrm{mg} / 100 \mathrm{ml})$, TmP/GFR $0.84 \mathrm{mmol} / 1$ glomerular filtrate $(2.6 \mathrm{mg} / 100 \mathrm{ml}$ glomerular filtrate), 24-hour urinary calcium $3.12 \mathrm{mmol}(125 \mathrm{mg})$, and immunoassayable parathyroid hormone $<0 \cdot 1 \mu \mathrm{g} / \mathrm{l}$. The hypercalcaemia was not suppressed with hydrocortisone. A satisfactory explanation for his symptoms was not found but they abated. Because he was believed to have familial hypocalciuric hypercalcaemia surgery was not considered. Investigations of his family were incomplete; his mother had hypercalcaemia but showed no symptoms.

\section{INDEX CASE 4}

A 19-year-old Caucasian man was admitted in October 1979 for further assessment of pancreatitis and hypercalcaemia not suppressed with hydrocortisone. Neck exploration had been done in July 1979 and no parathyroid tissue identified; after further episodes of pancreatitis laparotomy was performed. The gall bladder was removed and the common bile duct explored but no stones or pancreatic pseudocysts found.

Further assessment confirmed hypercalcaemia (calcium $3 \cdot 15 \mathrm{mmol} / 1$ $(12.6 \mathrm{mg} / 100 \mathrm{ml})$, magnesium $1.04 \mathrm{mmol} / 1(2.5 \mathrm{mg} / 100 \mathrm{ml})$, phosphate $0.8 \mathrm{mmol} / 1(2.5 \mathrm{mg} / 100 \mathrm{ml}), 24$-hour urinary calcium $3 \mathrm{mmol}(120$ $\mathrm{mg}$ ), and immunoassayable parathyroid hormone $0.3 \mu \mathrm{g} / \mathrm{l})$. Primary hyperparathyroidism was believed to account for these findings and a second neck exploration performed. One parathyroid gland of normal size and histology was removed, but he remained hypercalcaemic.

In December 1979 he had another bout of pancreatitis and had a respiratory arrest after the administration of opiates. He continued to have episodes of pancreatitis at approximately three-weekly $\underline{W}$ intervals. Short courses of steroids aborted four clinical attacks of pancreatitis, but the pancreas became radiologically calcified. In November 1980 an inflamed, oedematous, and heavily calcified pancreas was found at laparotomy and seven-eighths removed by Professor Miles Irving. Detailed family studies showed hypercalcaemia in his mother and an aunt (fig 1).
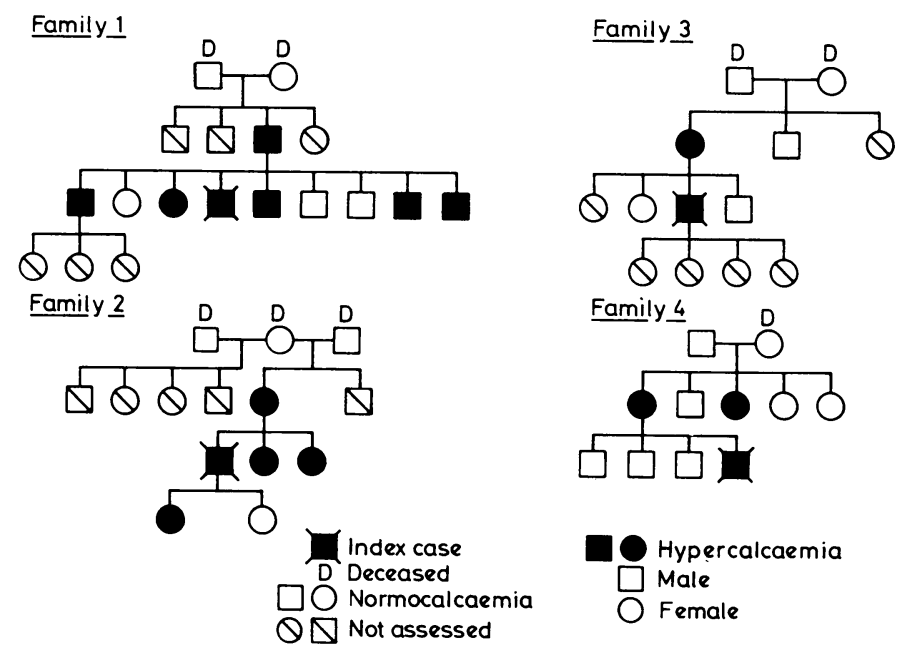

FIG 1-Family trees of the four index cases.

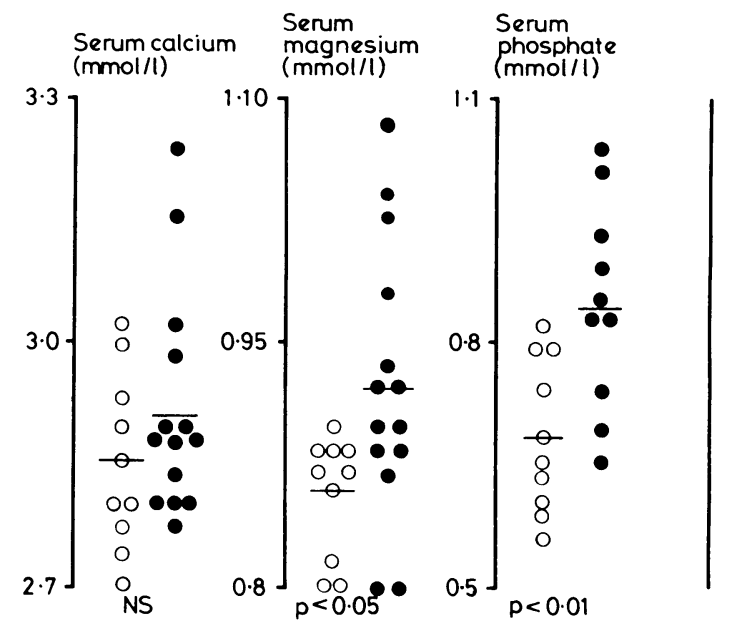

FIG 2-Serum calcium, magnesium, and phosphate concentration's in primary hyperparathyroidism (O) and familial hypocalciuric hypercalcaemia ( $)$. Horizontal bars represent mean values.

Conversion: $S I$ to traditional units-Serum calcium: 1 $\mathrm{mmol} / 1 \approx 4 \mathrm{mg} / 100 \mathrm{ml}$. Serum magnesium: $1 \mathrm{mmol} / 1 \approx$ $2.43 \mathrm{mg} / 100 \mathrm{ml}$. Serum phosphate: $1 \mathrm{mmol} / 1 \approx 3.1 \mathrm{mg} / 100$ $\mathrm{ml}$.

\section{Results}

Because the TmP/GFR and plasma phosphate concentration vary with age data from children and adolescents in the families (four cases) were excluded from the analysis. Immunoassayable parathyroid hormone was not measured in two children in the family of the first index case. Twenty-four-hour urine collections were not made by these two children or by the mother of the third index case. No results are included from three hypercalcaemic relatives in whom only the serum calcium concentration was known.

The biochemical findings in the probands and their affected relatives were compared with those in 10 patients with surgically proved primary hyperparathyroidism matched for serum calcium concentration (figs 2 and 3). The patients with familial hypercalcaemia differed significantly from the patients with primary hyperparathyroidism in 
having lower 24-hour urinary calcium excretion and enhanced renal tubular reabsorption of calcium as measured by fasting urinary calcium excretion. The mean serum phosphate concentration was significantly higher in the group with familial hypercalcaemia, as was the mean TmP/GFR, even though some patients had a reduced capacity to reabsorb phosphate from the renal tubule. Serum magnesium values tended to overlap, but the mean was significantly higher in the familial cases, while the mean serum concentration of immunoassayable parathyroid hormone was lower in the familial cases than in the patients with primary hyperparathyroidism.

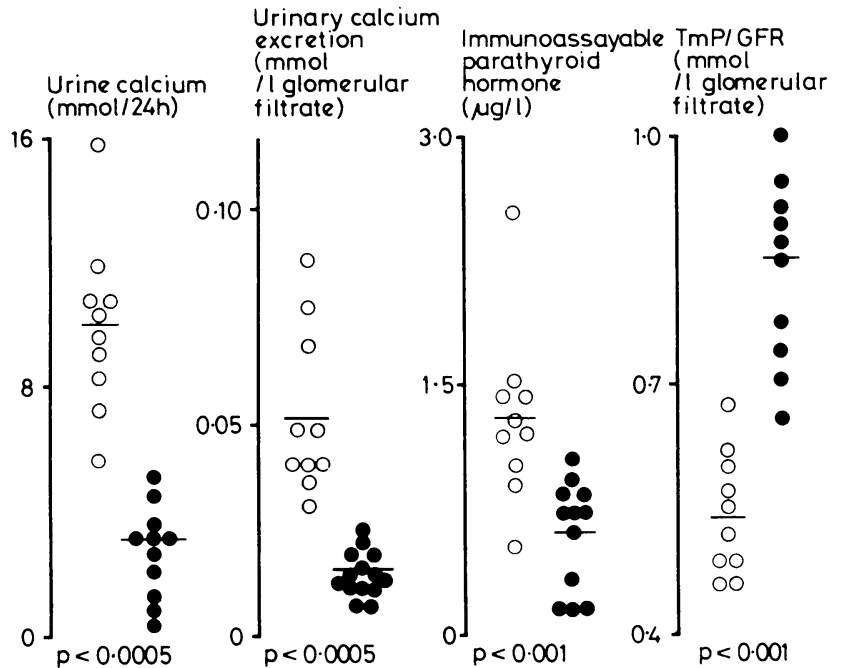

FIG 3-Urine calcium, urinary calcium excretion, immunoassayable parathyroid hormone, and TmP/GFR in primary hyperparathyroidism ( $O$ ) and familial hypocalciuric hypercalcaemia ( $)$. Horizontal bars represent mean values.

Conversion: SI to traditional units-Urine calcium: $1 \mathrm{mmol} / 24 \mathrm{~h} \approx 40$ $\mathrm{mg} / 24 \mathrm{~h}$. Urinary calcium excretion: $1 \mathrm{mmol} / 1$ glomerular filtrate $\approx 4$ $\mathrm{mg} / 100 \mathrm{ml}$ glomerular filtrate. TmP/GFR: $1 \mathrm{mmol} / 1$ glomerular filtrate $\approx$ $3.1 \mathrm{mg} / 100 \mathrm{ml}$ glomerular filtrate.

There was no significant difference in mean ( \pm SD) creatinine clearance (primary hyperparathyroidism $92 \pm 22 \mathrm{ml} / \mathrm{min}$; familial hypercalcaemia $102 \pm 20 \mathrm{ml} / \mathrm{min})$, urinary magnesium $(3.5 \pm 1 \mathrm{mmol} /$ $24 \mathrm{~h} v 3 \cdot 1 \pm 0.9 \mathrm{mmol} / 24 \mathrm{~h}(85 \pm 24 \mathrm{mg} / 24 \mathrm{~h} v 75 \pm 22 \mathrm{mg} / 24 \mathrm{~h}))$, or urinary magnesium excretion $0.018+0.009 v 0.018 \pm 0.008 \mathrm{mmol} / \mathrm{l}$ glomerular filtrate $(0.044 \pm 0.022 v 0.044 \pm 0.02 \mathrm{mg} / 100 \mathrm{ml}$ glomerular filtrate)).

\section{Discussion}

Familial hypocalciuric hypercalcaemia was first described in $1972,{ }^{2}$ and altogether 66 cases have been reported. Complications have been rare, pancreatitis has been described once, ${ }^{4}$ and most patients appear to have been asymptomatic.

The cases reported here had hypocalciuric hypercalcaemia with evidence of familial disease compatible with autosomal dominant inheritance (fig 1). Our experience differs from that of Marx et al $^{4}$ since three of the four index cases presented with acute pancreatitis, a recognised complication of hypercalcaemia and primary hyperparathyroidism. It is not surprising that symptomatic patients present in this way since they are unlikely, because of the hypocalciuria, to form renal stones. While most cases appear to run a benign course, index cases 2 and 4 had considerable morbidity.

Biochemical findings in familial hypocalciuria hypercalcaemia differ from those in primary hyperparathyroidism in several respects, and the changes documented here agree with some of those previously reported. ${ }^{12}{ }^{13}$ The diagnosis should be suspected in hypercalcaemic patients with a daily urinary excretion of calcium of less than $5 \mathrm{mmol}(200 \mathrm{mg})$ provided renal insufficiency, vitamin $\mathrm{D}$ deficiency, and the ingestion of drugs known to reduce calcium excretion have been excluded. Assess- ment of TmP/GFR and particularly fasting urinary calcium excretion provides further criteria for diagnosis. Over half the patients we describe had a normal TmP/GFR, and in only one was the value obtained comparable with those found in patients with primary hyperparathyroidism. Fasting urinary calcium excretion below $0.03 \mathrm{mmol} / 1$ glomerular filtrate $(0.12 \mathrm{mg} / 100 \mathrm{ml}$ glomerular filtrate) indicates hypocalciuric hypercalcaemia.

Assay of serum immunoassayable parathyroid hormone does not adequately discriminate between patients with familial hypocalciuric hypercalcaemia and those with primary hyperparathyroidism. ${ }^{13}$ The assay did, however, distinguish the patient with hyperplastic glands (case 1) from those with normal parathyroid glands (cases 2 and 4 ), in whom little or no hormone could be detected.

The precise aetiology of this condition and the pathophysiological role of the parathyroid glands remain obscure, but a much enhanced renal tubular reabsorption of calcium is characteristic. Whether this represents an intrinsic abnormality or a secondary response to extrarenal factors awaits evaluation. An abnormality of vitamin $\mathrm{D}$ metabolism appears unlikely, since preliminary data have shown normal serum concentrations of 1,25-dihydroxycholecalciferol compared with the often raised values found in primary hyperparathyroidism (EB Mawer, personal communication).

The management of these cases depends on accurate differentiation from primary hyperparathyroidism with, whenever possible, confirmatory evidence of familial disease. The results of subtotal parathyroidectomy have been disappointing: 33 operations have been carried out on 21 patients, of whom 18 remain hypercalcaemic and three have hypoparathyroidism. ${ }^{4}$ Our experience is similar, with three failed operations and one patient cured by inducing hypoparathyroidism with total parathyroidectomy. Surgical treatment should be reserved for those patients with severe, perhaps life-threatening, complications, when the surgeon should be prepared to remove all the identifiable parathyroid tissue.

We thank Professor S W Stanbury for permission to publish case 3 and Mrs B Bourne and Mr P Chambers for technical help. This work was in part supported by a programme grant from the DHSS and MRC to Professor S W Stanbury.

\section{References}

1 Peters N, Chalmers TM, Truscott BMcN, Rack JH, Adams PH. Familial hyperparathyroidism. Postgrad Med f 1966;42:228-33.

${ }^{2}$ Foley TP, Harrison HC, Arnaud CD, Harrison HE. Familial benign hypercalcaemia. $\mathcal{F}$ Pediatr $1972 ; 81: 1060-7$

${ }^{3}$ Marx SJ, Spiegel AM, Brown EM, Aurbech GD. Family studies in patients with parathyroid hyperplasia. Am 7 Med 1977;62:698-706.

4 Marx SJ, Stock JL, Attie MF, et al. Familial hypocalciuric hypercalcaemia: recognition among patients referred after unsuccessful parathyroid exploration. Ann Intern Med 1980;92:351-6.

5 Spiegel AM, Harrison H, Marx SJ, et al. Neonatal primary hyperparathyroidism with autosomal dominant inheritance. $f$ Pediatr 1977;90: 269-72.

6 Marx SJ. Familial hypocalciuric hypercalcaemia. $N$ Engl f Med 1980; $303: 810-1$

${ }^{7}$ Davies M, Mawer EB, Adams PH. Vitamin D metabolism and the response to 1,25-dihydroxycholecalciferol in osteoporosis. $\mathcal{f}$ Clin Endocrinol Metab 1977;45:199-208.

${ }^{8}$ Walton RJ, Bijvoet OLM. Nomogram for derivation of renal threshold phosphate concentration. Lancet 1975 ;ii:309-10.

9 Nordin BEC, Hodgkinson A, Peacock M. The measurement and the meaning of urinary calcium. Clin Orthop 1967;52:293-322.

${ }_{10}$ Mawer EB, Backhouse J, Hill LF, et al. Vitamin D metabolism and parathyroid function in man. Clin Sci Mol Med 1975;48:349-65.

11 Dent CE, Watson L. The hydrocortisone test in primary and tertiary hyperparathyroidism. Lancet 1968;ii:662-4.

12 Marx SJ, Spiegel AM, Brown EM, et al. Divalent cation metabolismfamilial hypocalciuric hypercalcaemia versus typical primary hyperparathyroidism. Am $\mathcal{F} M e d 1978 ; 65: 235-42$.

${ }^{13}$ Marx SJ, Spiegel AM, Brown EM, et al. Circulating parathyroid hormone activity: familial hypocalciuric hypercalcaemia versus typical primary hyperparathyroidism. F Clin Endocrinol Metab 1978;47:1190-7.

(Accepted 15 Fanuary 1981) 